\title{
Increasing Students' Understanding of the Simple Past Tense Using Discovery Learning at VII grade students of SMP Negeri 4 Doloksanggul in Academic Year 2017/218.
}

\author{
Holmes Rajagukguk M.Hum ${ }^{1}$, Dia Sinta Gultom²
}

\author{
${ }^{1}$ Faculty of Teacher Tranining and Education, Sisingamangaraja XII University, Indonesia \\ Email: holmesrajagukguk540@gmail.com \\ ${ }^{2}$ Faculty of Teacher Training and Education, Sisingamangaraja XII University, Indonesia \\ Email: diasinta@gmail.com
}

\begin{abstract}
The purpose of this research is to know whether students' understanding of the simple past tense could be increased by discovery learning. This research was conducted at VII grade students of SMP Negeri 4 Doloksanggul in Academic Year 2017/218.which consisted of 36 students as respondent. This research used Classroom Action Research (CAR) method in solving the students' problem in understanding of the simple past tense. The researcher used the Kurt Lewin's model that consists of four phases, planning, acting, observing and reflecting. There are two kinds of data in this research, namely quantitative and qualitative data. The quantitative data can be derived from the test result. Besides, the qualitative data can be derived from the observation, interview and field notes. In analyzing the data, the researcher used descriptive analysis and statistic analysis to know the result of the implementation the Classroom Action Research (CAR) to the students. The result of this study showed that the students ' progress during teaching and learning process using discovery learning to increase the students' understanding of the simple past tense was good. It was proved by three data results, first, from the observation result, it showed that the students were more motivated, active and interested in learning simple past tense in the classroom. Second, from interview result, it could be seen that students' skill in understanding of the simple past tense has improved than before in which suitable with interview result with the English teacher. Last, from the test result. It consisted of three tests, namely pretest, posttest 1 and posttest 2. There was found 22.78 point of improvement of students' mean score after using discovery learning. The mean score of the pre-test was 48.19. There were only $8.33 \%$ of the whole students who could pass Kriteria Ketuntasan Minimal (KKM). Then the mean score of posttest 1 was 59.86. The percentage of students was $33.33 \%$ who could
\end{abstract}

get the score above Kriteria Ketuntasan Minimal (KKM). Next, the mean score of posttest 2 was 70.97. In this test, there were $77.78 \%$ students who got the score above Kriteria Ketuntasan Minimal (KKM).

Keywords-Simple Past Tense, Discovery Learning.

\section{INTRODUCTION}

Nowadays standard competence and basic competence of School-Level Curriculum at class VII grade: Standard competence is expressing the meaning of short functional text and short essay in the recount and narrative form to interact with the environment. Basic competence is expressing the meaning and rhetoric step in short essay using written language accurately, clearly and acceptably to interact with the environment in the recount and narrative form. (Translated from the original of SchoolLevel Curriculum (KTSP), see the appendix XVI). Based on the standard and basic competence above, it is clear that the students at VII grade are expected to comprehend the narrative and recount text. Actually both use simple past tense in their construction of sentence. So they must master the simple past tense, because it can make them to be easier in comprehending both texts. However, unfortunately most of Seventh grade students of SMP Negeri 4 Doloksanggul are still difficult to understand simple past tense the writer found that most of students have some problems in understanding of the simple past tense such as: first, they are still confused in distinguishing between verbs which are included in regular verb and are included in irregular verb.

\section{REVIEW OF LITERATURE}

According to John Eastwood in his book Oxford Practice Grammars with Answers (Second Edition), he declared that "in the simple past tense, a regular past form end in ed, some verbs have an irregular past form ... we use did 
and also were and was in negatives and questions.

Moreover, in English Grammar in Use, Raymond Murphy said that "very often the past simple ends in -ed (regular verb). Example: the police stopped me on my way home last night. But many verbs are irregular. The past simple does not end in -ed." For example:

Get

got up early this morning.

Go

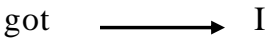

younger sister went to my party last night.

There are some formulas in the simple past tense:

\section{Affirmative statements}

To make an affirmative statements, the verb other than be, we use the following formula:

$$
\mathrm{S}+\mathrm{V}_{2}+(\mathbf{O} / \mathrm{Adv})
$$

Example: I went to Jakarta yesterday.

\section{Negative statements}

To make a negative statements, the verb other than be, we use the following formula:

$$
\mathrm{S}+\mathrm{DID}+\mathrm{NOT}+\mathrm{V}_{1}+(\mathrm{O} / \mathrm{Adv})
$$

Example: I didn't watch TV yesterday

He didn't study English language last night.

\section{Interrogative statements}

1. To make the interrogative statements of verb other than be, we put did before the subject, the formula is:

2. To make interrogative negative form of verb other than be based on this formula:

$$
\mathrm{DID}+\mathrm{S}+\mathrm{V}_{1}+(\mathrm{O} / \mathrm{Adv})
$$

Example: Didn't you study English lesson last night?

Didn't she bring the umbrella?

\section{The Use of Simple Past Tense}

According to A.J. Thomson and A.V. Martinet said that there are uses for the relation of past events:

1. It is used for actions completed in the past at a definite time. It is therefore used: For a past action when the time is given:

I went to the zoo yesterday

Michael Jackson died I 2000

Or when the time is asked about:

When did you arrive at my home?

2. Or when the action clearly took place at a definite time even though this time is not mentioned: The bus was ten minutes late.

3. Sometimes the time becomes definite as a result of a question and answer in the present perfect:
Where have we been?

\section{The Strategies of Using Discovery Learning}

According to Romiszowski that is quoted by William J. Rothwell, and H. Kazanas in their book Mastering instructional Design Process a Systematic Approach Second Edition, they said that "in discovery learning, learning is intensely personal. Set in the intimate mental world of the learner, it results not so much from manipulation of environmental variables outside the learner as from the learners' own internalized insight, reflection, and experience. Besides, Friedler, Nachmias, and Linn said that "the discovery learning processes as: (a) define a problem, (b) state a hypothesis, (c) design an experiment, (d) observe, collect, analyze, and interpret data, (e) apply the results; and (f) make predictions on the basis of results of previous experiment(s). ${ }^{22}$ It means that the strategy of discovery learning is to make the learners get the knowledge automatically after they had analyzed, evaluated and synthesize the information that had been learned. In addition, the process of discovery learning involves cognitive transformations of what Ausubel refers to substrate propositions which consist of problem setting propositions that are acquired by meaningful reception learning and background propositions already present within cognitive structure. Actually reception learning or discovery learning can be rote or meaningful. Everything depends upon how the knowledge is treated. If the learner merely memorizes the material (even if the conclusions have been arrived at by the discovery method).

Teaching Simple Past Tense Using Discovery Learning There are some steps in the teaching simple past tense using discovery learning as described in the figure below: Step 1 (Explanation): Teacher gives many examples of simple past tense which consists of regular verb, irregular verb, affirmative sentence, negative sentence, and interrogative sentence. She teaches all of examples by using question-answer drill that relates with the events in the past. Then she explains about what simple past tense is.

Step 2 (Guided Discovery): Teacher guides students in searching for the similarities and differences in each sentence. If they succeed in finding that at is used to show an exact time, then teacher ask them if there are any regularities underlying each expression. Be aware that although the teacher will deliberately guide students towards the rules to be discovered, students should be left to a certain extent to discover the rules for themselves.

Step 3 (Self-directed Discovery): After students have realized what the rules are, the students can have fun creating their own sentences before moving on to the next activity. 


\section{RESEARCH METHODOLOGY}

The research method in this study is an action research. According to Eileen Ferrance stated that "Action research is a process in which participants examine their own educational practice systematically and carefully, using the techniques of research". Furthermore, according to Edward L. Vockell and J. William Asher, they assert that action research refers to the practical application of the scientific method or other forms of disciplined inquiry to the process of dealing with everyday problems. It is particularly focused on teachers and other educators doing action research in order to make their particular educational activities more productive. In addition, actually action research is problem- focused, because it is nearly always arises from specific problem or issue arising out of professional practice. It means that action research focuses on problem and practical intended in its outcome. Besides, action research provides teachers and administrators with an opportunity to better understand what happens in their school. This process establishes a decision-making cycle that guides instructional planning for the school and individual classrooms. The writer used two cycles which each cycle has four phases: planning, acting, observing, and reflecting. The subject of this study was the seventh grade of SMP Negeri 4 Doloksanggul in academic year of 2018/2019. The place of the research was in SMP Negeri 4 Doloksanggul which is located in Humbang Hasundutan. The researcher chooses this school because it is one of the schools that writer doing PPL.

IV. FINDING AND DISCUSSION The Students' Simple Past Tense Score of Pretest, Posttest 1, and Posttest 2

\begin{tabular}{|c|c|c|c|}
\hline $\begin{array}{c}\text { Students' } \\
\text { Number }\end{array}$ & Pretest & Posttest 1 & Posttest 2 \\
\hline $\mathbf{1}$ & 40 & 60 & $\mathbf{6 5}^{*}$ \\
\hline $\mathbf{2}$ & 55 & 60 & $\mathbf{7 5}^{*}$ \\
\hline $\mathbf{3}$ & 50 & $\mathbf{6 5}^{*}$ & $\mathbf{7 0}^{*}$ \\
\hline $\mathbf{4}$ & 40 & 55 & 60 \\
\hline $\mathbf{5}$ & $\mathbf{6 5}^{*}$ & $\mathbf{7 0}^{*}$ & $\mathbf{8 5}^{*}$ \\
\hline $\mathbf{6}$ & 55 & $\mathbf{7 5}^{*}$ & $\mathbf{8 5}^{*}$ \\
\hline $\mathbf{7}$ & 50 & $\mathbf{7 0}^{*}$ & $\mathbf{7 5}^{*}$ \\
\hline $\mathbf{8}$ & 45 & 55 & $\mathbf{7 0}^{*}$ \\
\hline $\mathbf{9}$ & 30 & 50 & 55 \\
\hline $\mathbf{1 0}$ & 40 & $\mathbf{6 5}^{*}$ & $\mathbf{7 0}^{*}$ \\
\hline $\mathbf{1 1}$ & 45 & 60 & $\mathbf{7 5}^{*}$ \\
\hline $\mathbf{1 2}$ & 35 & 50 & 55 \\
\hline $\mathbf{1 3}$ & 40 & $\mathbf{7 0}^{*}$ & $\mathbf{8 0}^{*}$ \\
\hline $\mathbf{1 4}$ & 55 & 60 & $\mathbf{7 5}^{*}$ \\
\hline $\mathbf{1 5}$ & 60 & $\mathbf{7 0}^{*}$ & $\mathbf{7 5}^{*}$ \\
\hline $\mathbf{1 6}$ & 40 & 60 & $\mathbf{7 0}^{*}$ \\
\hline $\mathbf{1 7}$ & 45 & $\mathbf{6 5}^{*}$ & $\mathbf{7 5}^{*}$ \\
\hline $\mathbf{1 8}$ & 55 & 60 & $\mathbf{7 0}^{*}$ \\
\hline
\end{tabular}

\begin{tabular}{|c|c|c|c|}
\hline $\mathbf{1 9}$ & 40 & 45 & 55 \\
\hline $\mathbf{2 0}$ & 40 & 60 & $\mathbf{7 0}^{*}$ \\
\hline $\mathbf{2 1}$ & 35 & 45 & $\mathbf{7 5}^{*}$ \\
\hline $\mathbf{2 2}$ & 45 & 60 & $\mathbf{7 0}^{*}$ \\
\hline $\mathbf{2 3}$ & $\mathbf{6 5}^{*}$ & $\mathbf{7 0}^{*}$ & $\mathbf{8 5}^{*}$ \\
\hline $\mathbf{2 4}$ & $\mathbf{6 5}^{*}$ & $\mathbf{7 0}^{*}$ & $\mathbf{8 0}^{*}$ \\
\hline $\mathbf{2 5}$ & 55 & 60 & $\mathbf{7 0}^{*}$ \\
\hline $\mathbf{2 6}$ & 45 & 55 & $\mathbf{6 5}^{*}$ \\
\hline $\mathbf{2 7}$ & 40 & 50 & $\mathbf{7 5}^{*}$ \\
\hline $\mathbf{2 8}$ & 50 & 55 & $\mathbf{6 5}^{*}$ \\
\hline $\mathbf{2 9}$ & 55 & 60 & $\mathbf{7 5}^{*}$ \\
\hline $\mathbf{3 0}$ & 45 & 50 & 55 \\
\hline $\mathbf{3 1}$ & 40 & 55 & $\mathbf{6 5}^{*}$ \\
\hline $\mathbf{3 2}$ & 50 & 55 & $\mathbf{7 0}^{*}$ \\
\hline $\mathbf{3 3}$ & 60 & $\mathbf{6 5}$ & $\mathbf{7 5}^{*}$ \\
\hline $\mathbf{3 4}$ & 45 & 55 & $\mathbf{7 0}^{*}$ \\
\hline $\mathbf{3 5}$ & 55 & 60 & $\mathbf{7 5}^{*}$ \\
\hline $\mathbf{3 6}$ & 60 & $\mathbf{6 5}$ & \\
\hline $\begin{array}{c}\text { Mean: } \\
\mathbf{X}=\sum \mathbf{x}\end{array}$ & $\mathbf{4 8 . 1 9}$ & $\mathbf{5 9 . 8 6}$ & $\mathbf{7 0 . 9 7}^{*}$ \\
\hline $\mathbf{N}$ & & & \\
\hline
\end{tabular}

*The students who passed the Kriteria Ketuntasan Minimal (65)

Based on the table above, there are three tests which were conducted by the writer, namely pretest, posttest 1 and posttest 2. To analyze all data, the writer would calculate the students mean score of the test, calculate the class percentage, and calculate the students' improvement score from pretest to posttest 1 until posttest 2 percentage. The percentage of students' score who passed Kriteria Ketuntasan Minimal (KKM) is $\mathbf{3 3 . 3 3 \%}$. It showed that there are 12 students who passed the KKM and 24 students who still below Kriteria Ketuntasan Minimal $(K K M)$. So there is improvement from the percentage of students' pretest score to the percentage of students' score in the posttest I (33.33\%). The students' improvements which pass Kriteria Ketuntasan Minimal (KKM) is 25\% $(33.33 \%-8.33 \%)$. The percentage of students' score who passed Kriteria Ketuntasan Minimal (KKM) is $\mathbf{8 6 . 1 1 \%}$. It showed that there are 31 students who passed the Kriteria Ketuntasan Minimal (KKM) and 5 students who still below the target of Kriteria Ketuntasan Minimal (KKM). So there is $77.78 \%$ of improvement in the students' percentage of posttest II score from the pretest $(8.33 \%)$ and from the percentage of students' score in the posttest I (33.33\%). Therefore, this Classroom Action Research (CAR) has enough successful, because it has achieved the target of CAR $(75 \%)$. Based on the result of the pretest, the posttest 1 and the posttest 2, the writer can interpret the data in detail as following: In the pretest result which was conducted by the writer before conducting the Classroom Action Research (CAR), it is showed that the mean of 
students' score on understanding of the simple past tense before using the discovery learning technique is 48.19 . Besides, the percentage of students who passed Kriteria Ketuntasan Minimal (KKM) is $8.33 \%$. It could be happened; because there are only 3 students who could pass Kriteria Ketuntasan Minimal (KKM) and 33 students still got the score below the target of Kriteria Ketuntasan Minimal (KKM). Then after getting the pretest result, the writer conducted the Classroom Action Research (CAR) by applying the discovery learning technique and conducted the posttest 1 in the end of action in order to know whether any improvement or not in applying the technique of discovery learning. Based on the posttest 1 result, it is known that the mean of students' score is 59.86. It proved that there are some improvement of students' score from the pretest that is 11.67 (59.86 48.19 ) or $24.21 \%$. Moreover, the percentage of students who passed Kriteria Ketuntasan Minimal (KKM) in the posttest 1 is $33.33 \%$. It is known that there are 12 students who pass Kriteria Ketuntasan Minimal (KKM) and there are 24 students who still below the target of Kriteria Ketuntasan Minimal (KKM). Consequently, the writer continued to conduct this Classroom Action Research (CAR) in the next cycle, because it had not achieved the target yet of success CAR criterion that is $75 \%$ (or at least 27 students) from the students' percentage which pass Kriteria Ketuntasan Minimal (KKM). Next, the writer accomplished the posttest of cycle II. Based on the posttest II result, it is showed that the mean of students' score is 70.97. it means there is 11.11 point of improvement of students' score from posttest II to the posttest I (59.86) that can be seen in this calculation (70.97 - 59.86) and there is 22.78 point of improvement of students' score from posttest II to pretest (48.19). Furthermore, in the percentage of students who passed Kriteria Ketuntasan Minimal (KKM) in the posttest II shows that there is $77.78 \%$ of improvement in the students' percentage from the pretest $(8.33 \%)$ and there is 52.78 point of improvement from the percentage of students' score in the posttest II to the posttest I (33.33\%). Therefore, this Classroom Action Research (CAR) is success and stops the cycle, because there is above $75 \%$ students who passed Kriteria Ketuntasan Minimal (KKM).

\section{CONCLUSION}

Based on the result of the research that was conducted at VII grade students of SMP Negeri 4 Doloksanggul in academic year 2017/2018, it can be concluded that using discovery learning technique is a good technique in improving the students' understanding of the simple past tense. It can be proved based on the several data, such as: first, from the observation result showed that the students were more creative, active and independent in expressing what they have known. Also they were motivated in learning grammar which was regarded as the difficult lesson before. Second, based on the interview result, it could be summed up that students not only could induce the simple past tense rules underlying the examples well but also could improve their understanding of applying the simple past tense rules than before. Third, based on the test result, there was found an improvement of students' score from pretest to the second posttest of second cycle. The mean of pretest is 48.19 . There were only three students who passed Kriteria Ketuntasan Minimal $(K K M)$. Besides, the mean of the posttest in cycle 1 is 59.86, and there were 12 students who could pass Kriteria Ketuntasan Minimal (KKM). Even the mean of the posttest of cycle 2 is very increasing, it can achieve 70.97. There were many students who could pas s Kriteria Ketuntasan Minimal (KKM). Comparing between the pretest and posttest in cycle 2, there was found 22.78 point of improvement in students' score. Therefore, the discovery learning in teaching simple past tense is very good technique which is suitable to be applied at VII grade students of SMP Negeri 4 Doloksanggul. Also this Classroom Action Research (CAR) had been successful in achieving the target of CAR success criteria.

\section{REFERENCES}

[1] Aronson, Trudy. English Grammar Digest. Englewood Cliffs N. J.: Prentice-Hall, Inc. 1984.

[2] Azar, Betty Schrampfer. Fundamental of English Grammar. 3rd ed. Englewood Cliffs N.J. : Prentice Hall, 2003.

[3] __, Understanding and Using English Grammar. Englewood Cliffs N.J. : Prentice Hall Inc., 1989.

[4] Brown, James Dean. Testing in Language Programs: A Comprehensive Guide to English Language Assessment. New York: McGraww-Hill Companies, 2005.

[5] __, and Thom Hudson, Criterion-Referenced Language Testing. New York: Cambridge University Press, 2002.

[6] Eastwood, John. Oxford Practice Grammars with Answers. 2nd ed. Oxford: Oxford University Press, 1999. 